\title{
The Authority of Governments Regarding the Regulation and Supervision of Nuclear Mining Licensing on Business Perspectives in Indonesia
}

\author{
Khrisna Hadiwinata* \\ General Course Department \\ State Polytechnic of Malang \\ Malang, Indonesia \\ *khrisna.hadiwinata@polinema.ac.id
}

\author{
Nandaru Ramadhan \\ Faculty of Law \\ Universitas Brawijaya \\ Malang, Indonesia
}

\begin{abstract}
Mining products are one of Indonesia's potentials. Potention that has not maximized is potention of uranium, which is estimated to reach 7,000 tons, which distributed in Melawi, West Kalimantan, Bangka Belitung, Mamuju, West Sulawesi, Sibolga, North Sumatra, and Biak Papua. This number may still increase because in Kalan, Melawi has been confirmed to contain Uranium by BATAN. The potential and risks possessed by nuclear material makes the writer interested in researching about "The Authority of Regional Governments related to the Regulation and Supervision of Nuclear Mining Licensing in Indonesia." The problem is, the regulation related to the licensing of nuclear mines in Indonesia and the authority by the government regarding the regulation and supervision of nuclear mines in Indonesia. Regulations regarding the mining of nuclear materials in Indonesian legislation are still unclear and fragmented. The absence of radioactive mineral mining regulations is also a barrier besides obstacles such as a lack of budget and Indonesia's geological conditions. Arrangements made must pay attention to the local government, because the local government will be directly affected by this mining process. In addition, principles based on international conventions on nuclear and environment must be considered in drafting process relevant Government Regulations.
\end{abstract}

Keywords: authority, local government, Nuclear Mining

\section{INTRODUCTION}

Mining products are one of Indonesia's potentials. One potential that has not yet been maximized is the potential supply of uranium, which is estimated to reach 7,000 tons, which is estimated to be distributed in Melawi, West Kalimantan, Bangka Belitung, Mamuju, West Sulawesi, Sibolga, North Sumatra, and Biak Papua. This number may still increase because only in Kalan, Melawi has been confirmed to contain Uranium by BATAN [1].

Uranium is a radioactive material, which is a very potential energy. In some developed countries the utilization of nuclear power in various fields of public life, such as in the fields of research, agriculture, health, industry, and energy has been so rapid that as an effort to fill national development and the realization of people's welfare and prosperity and the achievement of the mastery of nuclear technology , then naturally it is sufficiently large that nuclear power potential is developed and utilized for the greatest prosperity of the people. However, in addition to the enormous benefits that nuclear power also has the potential for radiation hazards to workers, members of the public, and the environment when in the use of nuclear power, the provisions on nuclear safety are not heeded and are not properly monitored.

One example of the potential danger posed by nuclear power is the Chernobyl disaster and the Fukushima disaster. The two incidents were nuclear incidents which reached a scale of 7 on the INES scale. The impact of the incident was huge, but the potential generated from nuclear energy was also large. Regulations related to nuclear power are regulated in Act Number 10 of 1997 concerning Nuclear Energy.

Before Law Number 10 of 1997 concerning Nuclear Energy was in force, the applicable Law was Law Number 31 of 1964 concerning Basic Provisions for Atomic Energy. The development of the times and the advancement of science and technology in the use of nuclear power have resulted in many provisions in the law that are no longer appropriate, for example the authority to carry out and supervise research and use of nuclear power given in one body so that the oversight function is not optimal. In addition, nuclear materials must be owned and controlled by the state, while the sale and purchase of these materials has been carried out internationally so that the requirements that must be owned by the state will hamper the development of nuclear power utilization. However, the requirements that must be controlled by the state are maintained because despite the international free trade in nuclear materials, the Government is still required to conduct surveillance so that there is no deviation from the intended use of nuclear materials. Therefore, it is deemed necessary to make a new law on nuclear energy to replace Law Number 31 of 1964 concerning Basic Atomic Energy Provisions [2]

The authority for implementation and supervision is separated in two different institutions to avoid overlapping of utilization and supervision activities and at the same time optimize oversight aimed at further improving nuclear safety. In view of the nuclear concerns regarding the lives and safety of many people, the role of the community is enhanced in the form of a panel of considerations, a non-structural and independent institution composed of experts and community 
leaders, whose task is to provide advice and considerations regarding the use of nuclear power. To pay attention to the aspirations of the people developing in the community in the use of nuclear power, especially when building nuclear power plants, and providing a place for sustainable waste, the government before making a decision needs to discuss it with the House of Representatives of the Republic of Indonesia. The use of nuclear power must pay attention to the principles of National Development, safety, security, security, health of workers and members of the community, protection of the environment, as well as the utilization of the greatest prosperity of the people. That means that the use of nuclear power for the welfare of the lives of many people must be done with efforts to prevent the emergence of radiation hazards to workers, the community and the environment.

The potential and risks possessed by nuclear material makes the writer interested in researching about "The Authority of Regional Governments related to the Regulation and Supervision of Nuclear Mining Licensing in Indonesia." The problem is, what is the regulation related to the licensing of nuclear mines in Indonesia and what is the authority owned by the government regarding the regulation and supervision of nuclear mines in Indonesia.

This research have 2 objective. First, to find out about the regulation related to the licensing of nuclear mines in Indonesia. Second, to find out about the authority owned by the government regarding the regulation and supervision of nuclear mines in Indonesia.

This research have 2 theory as legal material, that are the theory of authority and local government concept.

\section{A. Theory of Authority}

The terms power, authority and authority are often simply equated. The terms authority and power are often exchanged. Power has the meaning of the rule and the ruled [3].

Based on the above understanding, power can occur that has nothing to do with the law. Henc van Maarseven called blote match [4], as power that has nothing to do with the law while according to Max Weber, power that has to do with law is called rational or legal authority. Rational / legal authority is an authority based on a legal system that is recognized and adhered to by the community, also the rules are strengthened by the state.

In public law, power is related to authority [5]. Power and authority have the same meaning. The power and authority inherent in the legislative, executive and judiciary are formal powers. Power is the main element in the process of governance, the other elements are [6]:

- Law;

- Authority;

- Policy;

- Justice;

- Honesty;
Power is the driving force for the implementation of the state so that it is de staat in beweging so that the country can work and perform to serve its citizens. according to Miriam Budiardjo, power is the ability to influence the behavior of others to follow their desires. To exercise power, a ruler or organ is needed. The state is conceived of as a set of een ambten complex (positions) by a number of officials based on the construction of subject-obligations.

Thus, power has two aspects, namely political and legal aspects, whereas authority only has a legal perspective. Power can come from the constitution or outside the constitution, for example through a coup or war, while the authority comes from the constitution.

Authority is formal power derived from legislative power (by law) or derived from administrative executive power. Authority is the power over an area of government by a certain group of people [7]. Ateng Syafrudin believes there is a difference between the notion of authority and authority [8]. Authority is formal power that comes from legislation and authority is part of that authority. Authority is in the scope of public law, talking about government decisions and also the implementation of the tasks set in the legislation. Juridically, authority has the meaning of ability that comes from legislation and has legal consequences [9]. According to H.D. Stoud, authority briefly is all the rules regarding the use by the government as subjects of public law

\section{B. Local Government Concept}

The concept of government as an institution in the life of the state and society tends to be manifested in the form of government. Bureaucracy with the understanding as the most active party in the daily management of state power. Bureaucracy is also placed in the position of executing decisions that are formulated and issued by political leaders.

Government has strategic and essential values in the administration of the State. Bureaucracy is a large part and organization and is used to refer to all government officials in a country [10]. According to Max Weber in Parenti, an outline of the bureaucratic characteristics are [11]:

- Systematic mobilization of human energy and material resources to realize explicitly defined policy objectives or plans;

- The use of trained career workers who occupy positions not on the basis of descent and whose jurisdiction is limited has been specifically specified;

- Specialization of expertise and division of labor responsible to an authority or constituency.

It can also be said that government can be interpreted as a process where the government carries out its functions to achieve certain goals and objectives. Various agencies (Institutions) were formed to carry out their respective missions and functions within the framework of the country's goals and national ideals. Furthermore, the Government or government in the narrow sense is the holder of executive power, while in the broad sense, all Institutions and their activities in a country. So, 
it also concerns matters relating to legislative and judicial powers.

Government based on law is a government that upholds the rule of law and is not based on human will. Sudikno Mertokusumo said as governance not by man but by law [12]. In a country based on law, the law is placed as the highest reference in the administration of the state and its government (rule of law). In this case the law of rule of law adheres to the highest position of law [13]. The law is used as a guiding principle for all activities of state organs, government, officials and their people. This is in line with the principle of the distribution of power or the distribution of power of government (distribution of power) which is adopted by the 1945 Constitution which is intended to limit and prevent the possibility of accumulation or abuse of power in the governing body / institution or official.

Lord Acton in the above connection as quoted by Sri Soemantri Martosoewignjo said "Power tends to corrupt; and absolute power tends to corrupt absolutly [14]" which in essence means however small the power tends to be abused. Regarding the division of governmental power can occur horizontally between high state institutions or on the basis of joint expertise between departments, or vertically or on the basis of regional joints between the Central Government and the Government in the Regions [15]. In this connection, the birth of government in the regions of Indonesia is essentially a consequence of the State of Indonesia as a rule of law based on Pancasila.

Local / regional government as we know it today originated from the development of governance practices in Europe in the 11 th and 12th centuries. At that time regional units emerged at the basic level which naturally formed a governmental institution. Initially, the territorial units constituted a selfmanaged community of resident communities. In subsequent developments these community units were incorporated into the state administration system of a sovereign state.

Large and complex organizations such as the Indonesian state will not be efficient if administrative and political authority is placed in the central organizational / government hierarchy. So that the authority can be implemented efficiently and accountably, some authority is delegated to the regional government called decentralization. Thus, decentralization is the transfer of political and administrative authority from the central government to regional governments [16].

Rondinelli formulated that [17], Decentralization is the transfer of planning, decision making, or administrative authority from the central government to its field organizations, local government, or nongovernment organization. (decentralization is the transfer of planning, decision making, or administrative authority from the central government to regional organizations, regional administrative units, semiautonomous organizations, regional governments, or nongovernmental organizations / non-governmental organizations).

\section{LEGAL METHODS}

The research method used in this study is a normative juridical research method, with a statute approach and conceptual approach. The primary legal material used is regulation about nuclear and about mining, which is analyzed using the theory of authority.

\section{RESULTS}

\section{A. Regulations on Nuclear Mining Licensing in Indonesia}

Regulations regarding radioactive mineral mining are slightly different from conventional mineral mining. This is due to the high risk nature of radioactive minerals, such as radiation hazards to workers, surrounding communities and the environment if their utilization is not monitored intensively. Supervision is carried out by issuing regulations, conducting permits, as well as field inspections and evaluations to ensure there is no abuse. Radioactive mineral mining is alluded to in Law Number 4 of 2009 concerning Mineral and Coal Mining. In the elucidation of Article 34 Paragraph (2) of the Mining Law, regulations relating to radioactive minerals are delegated to the legislation in the nuclear sector. The law in question is Law Number 10 of 1997 concerning Nuclear Energy.

For the purpose of utilizing and supervising the use of radioactive materials, the government forms an Implementing Body and a Supervisory Agency that is directly responsible to the President. The formation of these two bodies is based on the Nuclear Law in Chapter II on Institutionality. Article 3 Paragraph (1) shows that BATAN has the authority as an implementing agency tasked with carrying out the use of nuclear power. In addition to the executing agency, Indonesia also has an implementing agency that specifically conducts supervision through regulations, permits, and inspections of nuclear power utilization activities in accordance with the mandate of Article 4 Paragraph (1). The body that mention before is the Nuclear Energy Supervisory Agency (BAPETEN).

Utilization under this nuclear law is broad in scope, including research, development, mining, manufacturing, production, transportation, storage, transfer, export, import, use, decommissioning, to waste management as written in Article 1 Number 4. Article 3 Paragraph (2) and Article 9 also explained that the implementation of exploration and exploitation of nuclear excavated materials was delegated to BATAN. However, Article 11 explains that BATAN is not permitted to carry out commercial activities, but only for noncommercial purposes only. Activities aimed at commercializing production are carried out by state-owned enterprises, cooperatives, and / or private entities.

For each use of nuclear power required a permit submitted to BAPETEN in accordance with the mandate of the law. This permit is regulated in Government Regulation No. 29/2008 concerning Permission for Utilization of Ionizing Sources and Nuclear Materials. Based on the government regulation, mining is included in the utilization of nuclear material which is then grouped in group A. In the explanation of Article 6 Letter $b$, it is stated that the scope of mining for said nuclear excavation covers a series of uninterrupted stages, starting from general investigation, exploration, exploitation, to produce a yellow cake with a concentration of uranium-like ingredients can be at least $60 \%$. Based on the attachment of this 
government regulation, the mining permit is valid for 3 years and can be extended.

This Government Regulation has been replaced by Government Regulation No. 2 of 2014 concerning Nuclear Installation Licensing and Nuclear Material Utilization. In the new Government Regulation, the provisions on radioactive mineral mining were abolished. Article 105 Paragraph (2) limits the use of nuclear materials to research and development, manufacture, production, storage, transfer, export, import and use. In other words, with the enactment of this regulation, no one can mine even BATAN. Nuclear mining materials are not specifically regulated in the Nuclear Law and the regulations under it while the Minerba Act bestows its regulation on the Nuclear Law, then there is a legal vacuum governing the mining of nuclear minerals.

\section{B. Authority Owned by Regions Related to Nuclear Mining Control in Indonesia}

Until now, there is still a legal vacuum governing nuclear excavation materials. As mentioned in the previous discussion, mining for nuclear minerals is not specifically regulated in the Nuclear Law and the regulations under it while the mine and coal Act bestows its regulation on the Nuclear Law. Efforts to regulate this matter have been started by BAPETEN since 2015, but until now the expected output in the form of Government Regulations has not yet been published.

BAPETEN as the supervisory body held a Workshop on Nuclear Mineral Mining on Thursday, February 12, 2015, in Jakarta, to provide preliminary information to related parties regarding the regulation of mining licenses for mining nuclear / mineral radioactive minerals in Indonesia and to obtain input in the context of drafting Conception Draft Regulations Government on the Licensing of Mining for Radioactive Nuclear / Mineral Minerals. The workshop was attended by the Ministry of Energy and Mineral Resources, Ministry of Law and Human Rights, Ministry of Environment and Forestry, Ministry of Home Affairs, Ministry of Industry, Ministry of Trade, Ministry of State Secretariat, Ministry of Ristekdikti, BATAN, BPHN, PT. Sucofindo, PT. BKI, PT. Timah, UI, UGM and the Regional Government of Bangka-Belitung, Central Kalimantan, West Kalimantan, East Kalimantan, West Sulawesi.

The workshop showed a positive first step towards the position of the regional government in the licensing of nuclear mining materials, because the provincial government was also invited to attend the workshop. Provincial governments invited to attend are regional governments whose territories contain uranium reserves. Law Number 23 of 2014 concerning Regional Government has handed over authority related to mining to the provincial and central government. However, it must be remembered that the most felt impact from mining is on the district / city level local government. So, the district / city regional government must continue to be involved in the licensing and supervision process.

The vacuum of norm that still exists today is a problem. The Indonesian government should immediately revise its laws and regulations and unite the provisions regarding nuclear mining into its own special law. The reason for this separation is due to the specificity of nuclear mining compared to mineral mining. Radioactive mineral mining must also be separated because if it is put together in a nuclear law, the regulation will become too general. It is also recommended that the Government include the principles of nuclear mining as adopted by nuclear producing countries. The World Nuclear Association (WNA) provides principles for managing radiation, health and safety, waste and the environment based on the WNA Ethics Charter and WNA Stewardship Principles and principles based on international conventions on nuclear and the environment [18].

The principles referred to are [19]:

- Subject to a sustainable development regime such as professionalism, transparency, accountability, and overall recognition of good business congruence and sound environmental practices;

- Health, safety and environmental protection. Mining operators must ensure mine safety, radiation safety, provide workers with protective equipment, provide ventilation, water checking and environmental protection from water, soil and air pollution;

- Fulfillment of security and safety standards as outlined in the International Atomic Energy Agency (IAEA) convention;

- Social responsibility, i.e. the operator must also pay attention to the response back from the surrounding community or involve public participation;

- Management of hazardous materials, including products, residues, waste, and materials contaminated with radioactive elements;

- Management of a quality system that includes planning and risk management

- Accidents and emergencies where the operator must identify and estimate the possibility of incidents and accidents as well as take control to minimize those possibilities;

- Transportation of hazardous materials which includes packing and shipping based on IAEA regulations on safe transportation of radioactive materials;

- A systematic training approach;

- Security of radioactive sources and closed nuclear substances;

- Decommissioning and closure of mining sites.

\section{CONCLUSION}

From the discussion above, it can be concluded as follows the regulations regarding the mining of nuclear materials in Indonesian legislation are still unclear and fragmented. Thus, the absence of radioactive mineral mining regulations is also a barrier besides obstacles such as a lack of budget and Indonesia's geological conditions, and the arrangements made must pay attention to the position of the local government, 
[8] A. Syafrudin, Menuju Penyelenggaraan Pemerintahan Negara yang Bersih dan Bertanggungjawab, Jurnal Pro Justicia Edisi IV, (Bandung Universitas Parahyangan, 200), Hlm. 22. by this mining process. In addition, principles based on international conventions on nuclear and environment must be considered in the process of drafting relevant Government Regulations.

\section{ACKNOWLEDGMENT}

Special Thanks to Dr. Shinta Hadiyantina for the assistance and support our research.

\section{REFERENCES}

[1] A.A. Chandra, RI Punya 7.000 Ton Uranium, Ini Dia Lokasinya, 2016. [Online], Available: https://finance.detik.com/energi/d-3201140/ripunya-7000-ton-uranium-ini-dia-lokasinya

[2] Penjelasan Undang-Undang Nomor 10 Tahun 1997 tentang Ketenaganukliran.

[3] M. Budiardjo, Dasar-Dasar Ilmu Politik, (Jakarta:Gramedia Pustaka Utama, 1998), Hlm. 35-36.

[4] S. Mulyosudarmo, Kekuasaan dan Tanggung Jawab Presiden Republik Indonesia: Suatu Penelitian Segi-Segi Teoritik dan Yuridis Pertanggungjawaban Kekuasaan, (Surabaya: Universitas Airlangga, 1990), Hlm. 30.

[5] P.M. Hadjon, Tentang Wewenang, Makalah, Universitas Airlangga, Surabaya, Hlm. 1

[6] R. Kantaprawira, Hukum dan Kekuasaan, Makalah, (Yogyakarta: Universitas Islam Indonesia, 1998), Hlm. 37-38.

[7] P. Atmosudirdjo, Hukum Administrasi Negara, (Jakarta: Ghalia Indonesia), Hlm. 78.

[9] Indroharto, Asas-Asas Umum Pemerintahan yang Baik, dalam Paulus Efendie Lotulung, Himpunan Makalah Asas-Asas Umum Pemerintahan yang Baik, (Bandung: Citra Aditya Bakti, 1994), Hlm. 65.

[10] P. Sondang, Siagian, Patologi Birokrasi, Mizan, Jakarta, 1998, h. 10.

[11] M. Parenti, Democracy for the Few . Fifth Edition, St Martin's Press, New York, USA, 1988, p. 75.

[12] S. Mertokusumo, Upaya Meningkatkan Supremasi Hukum, dalam Majalah Justitia Et Pax, Fakultas Hukum Univ. Atmajaya, Yogyakarta, Edisi Bulan Mei-Juni 2000 Thn. XX Nomor 19, h. 2.

[13] I. Suny, Mekanisme Demokrasi Pancasila, Aksara Baru, Jakarta, 1984, h.8.

[14] S.S. Martosoewignjo, Undang-Undang Dasar 1945, Kedudukan dan Artinya dalam Kehidupan Bernegara, Makalah yang disampaikan pada Stadium Generale dan Peringatan 40 Tahun Pengabdiannya di Univ. Padjadjaran Bandung, Bandung, 2001, h. 7.

[15] A. Muslimin, Beberapa Asas Dan Pengertian Pokok Tentang Administrasi Dan Hukum Administrasi, Penerbit Alumni, Bandung, 1985, h. 45.

[16] H. Nurcholis, Teori dan Praktek Pemerintahan Daerah, Grasindo, Jakarta, 2005, h.8.

[17] A. Dennis, Rondinelli, et. al.,. Government Decentralization in Comparative Perspective Theory and Practice in Developing Countris, Intemational Review of Adminstration Science, Vol.XL VIL No.2., 1981, p. 18.

[18] S. Carlton, B. Alec, P. Norbert, T. Wolfram, Handbook on Nuclear Law; IAEA, Vienna. 2003.

[19] IAEA; IAEA Safety Standard, www-ns.iaea.org. 